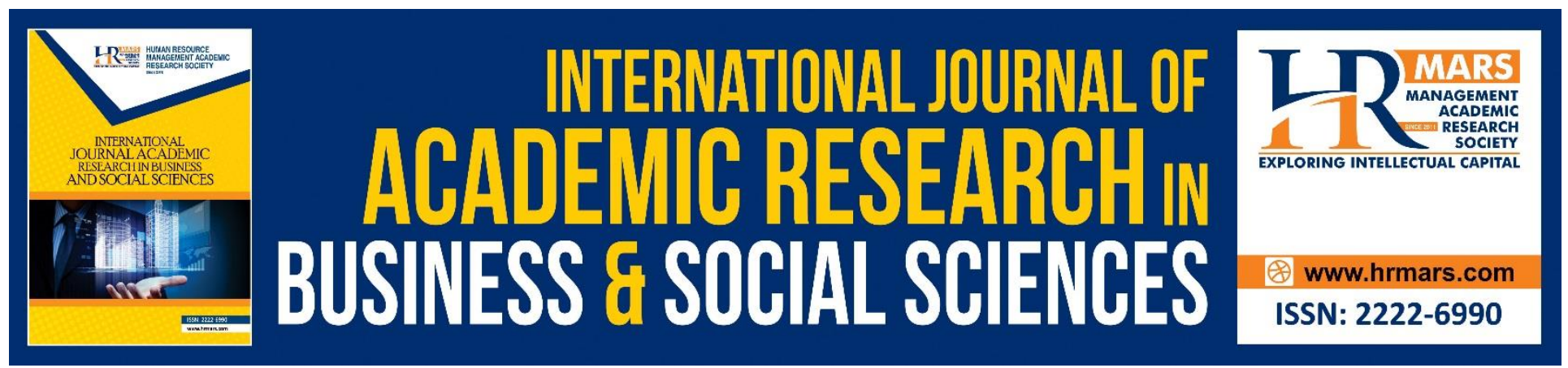

\title{
The Study on the Influencing Factors of Chinese Military Listed Companies' Operating Efficiency under Civil-Military Integration
}

Dongfang Qiu, Ming Qiu, Jie Tang, Qingwen Wang

To Link this Article: http://dx.doi.org/10.6007/IJARBSS/v9-i4/5835

DOI: $\quad 10.6007 /$ IJARBSS/v9-i4/5835

Received: 02 March 2019, Revised: 17 March 2019, Accepted: 30 March 2019

Published Online: 03 April 2019

In-Text Citation: (Qiu, Qiu, Tang, \& Wang, 2019)

To Cite this Article: Qiu, D., Qiu, M., Tang, J., \& Wang, Q. (2019). The Study on the Influencing Factors of Chinese Military Listed Companies' Operating Efficiency under Civil-Military Integration. International Journal of Academic Research Business and Social Sciences, 9(5), 201-213.

Copyright: (C) 2019 The Author(s)

Published by Human Resource Management Academic Research Society (www.hrmars.com)

This article is published under the Creative Commons Attribution (CC BY 4.0) license. Anyone may reproduce, distribute, translate and create derivative works of this article (for both commercial and non-commercial purposes), subject to full attribution to the original publication and authors. The full terms of this license may be seen

at: http://creativecommons.org/licences/by/4.0/legalcode

Vol. 9, No. 4, 2019, Pg. 201 - 213

http://hrmars.com/index.php/pages/detail/IJARBSS

JOURNAL HOMEPAGE

Full Terms \& Conditions of access and use can be found at http://hrmars.com/index.php/pages/detail/publication-ethics 


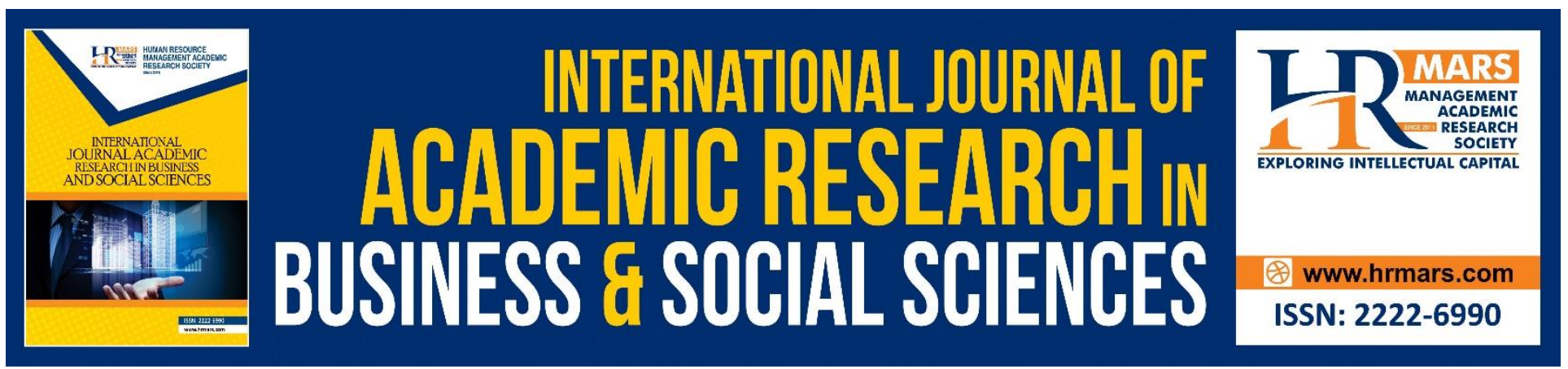

\title{
The Study on the Influencing Factors of Chinese Military Listed Companies' Operating Efficiency under Civil-Military Integration
}

\author{
Dongfang Qiư1, Ming Qiu², Jie Tang ${ }^{3}$, Qingwen Wang ${ }^{4}$ \\ 1,3,4 College of Economics and Management, Nanjing University of Aeronautics and Astronautics, \\ China. \\ 2 Business School Department, Nanjing University, China.
}

\begin{abstract}
Facing fierce domestic and international competition, military listed companies should not focus only on military benefits and should improve their own operating efficiency for long-term sound development. Objective: The aim of this paper is to analyze key factors that influence the operating efficiency of military listed companies. Results and Conclusion: The result shows that R\&D input and scale of company have a significant and positive impact on the operating efficiency of military listed companies. Meanwhile, government subsidies have a weak and negative effect.
\end{abstract}

Keywords: Under Civil-Military Integration, Military Listed Companies, Operating Efficiency, Data Envelopment Analysis, Individual Fixed Effect Model

\section{Review of Literature}

Military industry is a strategic industry related to national economic development and an important guarantee of national defense security. At the plenary session of the PLA delegation at the third session of the 12th National people's Congress, President Xi proposed a major decision of upgrading "military-civilian integration" into a national strategy, and the state issued a series of policies to promote the in-depth development of civil-military integration. Compared with foreign countries, Chinese listed military companies are far behind foreign first-class military in terms of scale, industry competitiveness, profitability and operating efficiency. In the face of rapid changes in the domestic and international competitive environment, the listed companies of military industry want to improve their competitive ability to obtain long-term development, which mainly depends on the improvement of operational efficiency.

Some scholars study abroad business performance evaluation and its influencing factors, in the 1980s, American management accounting committee issued "measuring corporate performance specifications", net profit, EPS, ROI, cash flow, residual income, economic income, the market value 
and adjusting the results after deflation is 8 indicators to measure the performance of enterprise management. Singha found that enterprise mergers and acquisitions would have an impact on operating efficiency (Singh \& Mogla, 2010). Martins found that intangible assets indeed have a correlation with business performance (Martins \& Lopes, 2016).

With the rise of "civil-military integration" as a national strategy, issues related to "civil-military integration" have become one of the hot spots in academic circles. On the whole, accelerating the implementation of the "civil-military integration" strategy is to revitalize the assets of the national defense and military fields and improve the efficiency of scientific and technological achievements transformation and production and operation in the national defense and military industries. Based on this background, domestic scholars conducted in-depth research on how to improve the operational efficiency of the military industry from the perspective of normative analysis and quantitative analysis. The normative analysis mainly starts from the national strategy of "civil-military integration" and discusses how to improve the operational efficiency of the military industry from the perspective of theory and policy system. Zhang Jihai and Qiao Jingjie believed that the essence of the civil-military integration strategy lies in the optimization of resource allocation, and the goal is to form a comprehensive, multi-field and high-efficiency development pattern of deep civil-military integration (Zhang \& Qiao, 2016). Pan Yue put forward countermeasures and suggestions on further enhancing the efficiency of military industrial core capacity investment and construction from four aspects: organizational innovation, financial innovation, technological innovation and business model innovation (Pan et al., 2017). The quantitative analysis mainly focuses on the measurement of operational efficiency of military listed companies and the research on factors influencing corporate performance. Guo Yonghui used DEA method to analyze the implementation effect of "military transformation to civilian" of military industrial listed companies and evaluated it (Guo , 2014). Li Ye constructed a three-line military industrial enterprise transformation and upgrading theoretical model from three aspects of operation system, technology and product (Li Y et al., 2015). Through factor analysis, it was also found that military industrial enterprises' transformation and upgrading were affected by eight internal and external factors, including local economy, policy, management mode and production capacity. Wang Baijie and Li Aiwen found that enterprise scale, product differentiation, enterprise registration place, level of market competition, change of capital stock structure, level of economic development, all contribute to the improvement of technical efficiency of civil-military integration enterprises (Wang \& Li, 2016). Jiong found that the overall operating efficiency of listed military companies grew slowly, while the comparative analysis found that the operating efficiency of "civilian military" companies was more advantageous than that of stateowned military enterprises (Zhou, 2012).

To sum up, scholars have conducted abundant researches on the transformation and upgrading, policy system improvement, business performance measurement and influencing factors of military enterprises under the background of "civil-military integration". However, there are still some limitations in the research on the operational efficiency of military listed companies. This article will make up for the shortcomings of previous studies, under the current situation of management of military industry listed companies to determine the DEA input-output index, analyzing the influencing mechanism of various potential influencing factors on operational efficiency of military listed 
INTERNATIONAL JOURNAL OF ACADEMIC RESEARCH IN BUSINESS AND SOCIAL SCIENCES Vol. 9, No. 4, April, 2019, E-ISSN: 2222-6990 @ 2019 HRMARS

companies and conduct empirical test, and studying the operational efficiency and influencing factors of military listed companies in China have great significance and practical reference value.

\section{Research Hypothesis}

\section{Operating Efficiency of Military Listed Companies}

The operating efficiency of an enterprise is determined by the combined effects of various factors and is subject to randomness. From the perspective of research, there are perspectives of external environment, institutional governance, and operational management. According to these three perspectives, the determinants of the efficiency of company operating can be divided into three levels: company management, corporate governance and the external environment. The level most directly related to the operating efficiency of a company is the level of business management. Second is the level of corporate governance that constrains the quality of corporate management and supports its operations. Third, it is the external environment, including the market structure, economic system, and policy support that affect corporate performance.

The impact of corporate governance on operating efficiency

The structure of corporate governance includes three aspects: capital structure, shareholding structure and principal-agent management. The ownership structure has a basic position in corporate governance. The internal governance arrangements of the company, such as the board structure and the equity incentives of managers, are actually the result of the company's internal power allocation. And the ownership structure is a direct reflection of the company's internal power allocation. As the basis of corporate governance, it directly affects the company performance. Therefore, this paper intends to select the ownership structure as an indicator of the influencing factors of corporate governance.

Military listed companies are mostly restructured from the high-quality assets of the top ten military enterprises. The ownership concentration and the proportion of state-owned shares are not the same as those of listed companies in other industries. Therefore, we choose the ownership concentration and the proportion of state-owned shares to measure the shareholding structure and explore the impact of the shareholding structure on operational efficiency. The ownership concentration reflects the concentration of the company's stock equity. This paper selects the equity ratio of the top 10 shareholders to measure the concentration of stock equity. The greater the shareholding ratio of the top 10 shareholders, the higher the concentration of the company's stock equity will be, and the smaller the impact of the pressure exerted by the other shareholders on the major shareholders. The higher degree of holdings, the less pressure the company handles external and internal oversight. The concentration of stock equity can affect the operating decisions of the company's senior executives by controlling the distribution of governance rights to a certain extent, which in turn affects the company's operating efficiency. Military listed companies with a high proportion of state ownership manage listed companies by entrusting professional managers. Due to the existence of the phenomenon of "insider" control, this layer-by-layer entrusted governance method increases the cost of agency. At the same time, as a shareholder, the state may exhibit excessive administrative intervention in the process of corporate governance, which will also have a 
political complexion in the company's decision-making process, thus inhibiting the enthusiasm and creativity of the micro-subject of the company. This has caused the negative efficiency of the operating efficiency of military listed companies. Therefore, this paper proposes the following assumptions:

Hypothesis 1: The ownership concentration in military listed companies had a significantly negatively correlated with operating efficiency (TE).

Hypothesis 2: The state-owned shareholding ratio of military listed companies had a significantly negatively correlated with operating efficiency (TE).

The impact of company management on operational efficiency

Enterprise management is divided into R\&D management, manufacturing management and marketing management. Due to the particularity of product manufacturing and sales targets of military listed companies, manufacturing management and marketing management are less important. Therefore, this paper only examines the impact of R\&D investment on operational efficiency. On the other hand, due to the particularity of the production technology and the large scale of investment of the military industry, many researchers believe that the military industry is a typical industry that can reach economies of scale. It can be seen from the relevant policies of the military industry in recent years in China that the government tends to increase the concentration of China's military industry and expand the scale of military listed companies through restructuring or asset restructuring. So it can be assumed that there is an economy of scale in China's military listed companies, that is, the larger the size of military listed companies, the higher the company's operating efficiency. Therefore, this paper proposes the following assumptions:

Hypothesis 3: R\&D investment in military listed companies had a significantly positively correlated with operating efficiency (TE).

Hypothesis 4: The size of the military listed company had a significantly positively correlated with operating efficiency (TE).

\section{The Impact of External Environment on Operational Efficiency}

Military industrial enterprises are the basic components of the defense technology industrial system, and also the main part of national defense scientific researching production activities. At present, the vast majority of China's military listed companies are listed after the restructuring of high-quality enterprises of state-owned military industrial groups. Therefore, its primary business objective at this stage is still to serve national security interests. The external environment of military listed companies is mainly the state's concern and investment in the military industry. Therefore, the impact of the external environment of military listed companies on operational efficiency can be measured by government subsidy indicators.

With the escalation of the national security strategy and the continued increase in defense military spending, the government has provided substantial financial support to the military industry. The military industry is an important part of the manufacturing industry and an important guarantee for national security. Judging from the government subsidies obtained from the military industry, the 
military industry has strong advantages, and the total amount of subsidies and the range subsidies are in the forefront of each sector. Consulting the annual report of military listed companies, we can find that the government's subsidies for military listed companies are mainly through financial subsidies and tax rebates. This paper manually extracts the ratio of the non-recurring gains and losses were recorded in the amount of government subsidies of the current profits and losses to the operating revenue in the current year in the annual report of the listed companies in the military industry, to measure the government's support for military listed companies. Therefore, this paper proposes the following assumptions:

Hypothesis 5: Government subsidies for military listed companies had a significant positive impact on operational efficiency (TE).

\section{The Index Selection and Model Construction}

Selection of operating efficiency and its influencing factors

For selecting the operating efficiency input-output indicators of military listed companies, basic requirements should be followed: Firstly, the selected input-output indicators can effectively reflect the operating efficiency of military listed companies. Secondly, avoid complete substitution or full complement at the same time between the indicators. Thirdly, the selected indicators should be operable, accessible and comparable.

For the study of enterprise operating efficiency, abundant achievements have been made by scholars at home and abroad. Due to the different characteristics of industries, the input-output indicators are also different when scholars using DEA method to calculate the operating efficiency. The research object of this paper is military listed companies, in order to ensure the scientific, comprehensive and applicable selection of input-output indicators. Combing the literature review of past DEA input and output indicators adopted by scholars and considering that the input-output index required by DEA model is homogeneous, this paper chooses the total assets, main business cost, the cash paid to the employees and the salary paid for the employees (hereinafter referred to as staff salaries) as the input index. While main business income, earnings per share and net profit attributable to shareholders of a listed company other than recurring gains and losses (hereinafter referred to as net profit excluding recurring gains and losses) are output indicators. The final input-output indicators used in operating efficiency evaluation of military listed companies are shown in Table 1, and the influencing factors and assignments of operating efficiency of military listed companies are summarized in Table 2. 
INTERNATIONAL JOURNAL OF ACADEMIC RESEARCH IN BUSINESS AND SOCIAL SCIENCES Vol. 9, No. 4, April, 2019, E-ISSN: 2222-6990 @ 2019 HRMARS

Table 1: Military listed companies operating efficiency of input and output indicators system

\begin{tabular}{|l|l|}
\hline Indicator category & Indicator name \\
\hline \multirow{4}{*}{ input indicators } & Total assets \\
\cline { 2 - 3 } & main business cost \\
\cline { 2 - 2 } & staff salaries \\
\hline \multirow{4}{*}{ output indicators } & main business income \\
\cline { 2 - 2 } & earnings per share \\
\cline { 2 - 2 } & $\begin{array}{l}\text { net profit attributable to shareholders of a listed company other than } \\
\text { recurring gains and losses }\end{array}$ \\
\hline
\end{tabular}

Table 2: Indicators and Assignments of Operating Efficiency of Military Listed Companies

\begin{tabular}{|c|c|c|c|}
\hline Indicator Category & Indicator name & Variable name & Assignment \\
\hline \multirow{2}{*}{$\begin{array}{l}\text { Corporate } \\
\text { Governance }\end{array}$} & $\begin{array}{l}\text { Ownership } \\
\text { Concentration }\end{array}$ & Top & $\begin{array}{l}\text { The sum of the shareholdings of } \\
\text { the top } 10 \text { largest shareholders }\end{array}$ \\
\hline & $\begin{array}{ll}\text { State } & \text { Shareholding } \\
\text { Ratio } & \end{array}$ & State & $\begin{array}{l}\text { Final state owned corporate } \\
\text { shareholding ratio }\end{array}$ \\
\hline \multirow{2}{*}{$\begin{array}{l}\text { Company } \\
\text { Management }\end{array}$} & R \& D Investment & $R \& D$ & $\begin{array}{l}\text { Proportion of R \& D investment } \\
\text { to operating income }\end{array}$ \\
\hline & Company size & Scale & Natural logarithm of total assets \\
\hline $\begin{array}{l}\text { External } \\
\text { Environment }\end{array}$ & Government grants & Subsidy & $\begin{array}{l}\text { Government subsidies account } \\
\text { for operating income }\end{array}$ \\
\hline
\end{tabular}

\section{Model Construction}

(1) Measuring model of operating efficiency

Data Envelopment Analysis (DEA) is an efficiency evaluation method proposed in 1978 for evaluating multi-input and multi-output, so as to evaluate the decision-making unit, which can ideally reflect the information and characteristics of the object itself (Charnes, et al., 1978). At present, DEA has been used by many scholars to study the efficiency of input and output, and has become a very important analytical tool in the fields of management science, system analysis, decision analysis and evaluation technology. DEA method includes CCR, BCC and other models. CCR model is the technical efficiency calculated under the constant return on scale as the comprehensive efficiency. This paper applies CCR model, which is an axiomatic model, to describe the scale of production and technical effectiveness. This model not only enlarges people's understanding of production theory, but also provides an effective way to evaluate multi-objective problems, which makes the main technical means of studying production function theory develop from parametric method to parametric and non-parametric method.

\section{Impact Model of Operating Efficiency}

According to the above factors, this paper will make an empirical analysis on the panel data of 38 military listed companies from 2014 to 2016. Based on the following reasons, the panel data regression analysis method is selected to identify the factors affecting the operating efficiency of 
military listed companies. Firstly, compared with time series model or cross-sectional data model, panel data model can combine the temporal and spatial characteristics of the data, reduce the heterogeneity between the military listed companies and explain the multiple collinearity between the variables when estimating the model parameters, so that the model estimation results are more robust; Secondly, there are many unique and non-time-varying factors affecting the operating efficiency of military listed companies, such as organizational system, corporate culture, business model and other factors, which cannot be observed in this paper, but can be controlled by the individual fixed effect in the model to overcome the effect of missing variables on the robustness of model estimation. Therefore, this paper uses the individual fixed effect model to study the significant heterogeneity between different samples. The model is as follows:

$T E_{i t}=\alpha_{1} D_{1}+\alpha_{2} D_{2}+\cdots+\alpha_{N} D_{N}+\beta_{1} T_{o p}+\beta_{2} T_{\text {Top }}+\beta_{3} R \& D_{i t}+\beta_{4}$ Subsidy $_{i t}+\varepsilon_{i t}, t=1,2, \cdots, N$

Among them: $D_{i}$ represents cross section individual dummy variables,

$D_{i}=\left\{\begin{array}{l}1, \text { if it belongs to the first i sample } \\ 0, \text { else }\end{array}, i=1,2, \cdots, N\right.$

$\mathrm{TE}_{\mathrm{it}}$ represents the comprehensive efficiency value of the first i military listed company in period $t, i$ represents the military listed company, $t$ represents the time; $\varepsilon_{i t}$ is a disturbance term that varies with individual and time changes.

Sample Selection and Data Processing

According to the list of Listed Companies in the defense sector issued by the Military Industry Committee of the Association of Listed Companies of China and excluding listed companies that have been specially processed and delisted for 2014-2016 years, this paper chooses 38 military listed companies as research samples with large business scale and high importance of military products business in all business of the company.

\section{Empirical Analysis}

Descriptive Statistics

(1) Descriptive statistics of operating efficiency of listed military enterprises

Based on the CCR model, this paper uses DEAP software to measure the operating efficiency from 2014-2016 of listed military enterprises. If the efficiency value is 1.00, it indicates that the input and output of the decision-making unit is comprehensively effective. Otherwise, it is invalid. The bigger the efficiency value is, the higher the efficiency of the decision-making unit is. The interval distribution of comprehensive efficiency evaluation of year 2014-2016's for the 38 listed military enterprises are in Table 3. In the past three years, the operating efficiency averages of 38 listed military enterprises were $0.9658,0.9643$ and 0.9687 , showing a trend of first decreasing and then increasing. From 2014 to 2016, 11, 15 and 17 enterprises separately reached the effective state of comprehensive efficiency, which shows an upward trend year by year, indicating that the operating efficiency of listed military enterprises is constantly improving. In 2014, 23 companies' comprehensive efficiency value exceeded the average level, approximately accounting for $61 \%$ of the 
INTERNATIONAL JOURNAL OF ACADEMIC RESEARCH IN BUSINESS AND SOCIAL SCIENCES Vol. 9, No. 4, April, 2019, E-ISSN: 2222-6990 C 2019 HRMARS

total sample enterprises. In 2016, this proportion increased to $66 \%$, indicating that the gap between the individual efficiency of the sample listed military enterprises was not so big.

Table 3: Interval Distribution of Comprehensive Efficiency for the 38 Listed Military Companies

\begin{tabular}{|l|l|l|l|l|l|l|}
\hline \multirow{2}{*}{ Interval Distribution } & \multicolumn{5}{l|}{ Sample Size } & \multicolumn{2}{l|}{ Proportion } \\
\cline { 2 - 8 } & 2014 & 2015 & 2016 & 2014 & 2015 & 2016 \\
\hline Comprehensive efficiency=1 & 11 & 15 & 17 & $29 \%$ & $39 \%$ & $45 \%$ \\
\hline $\begin{array}{l}0.95 \leq \text { Comprehensive efficiency } \\
<1\end{array}$ & 17 & 12 & 12 & $45 \%$ & $32 \%$ & $32 \%$ \\
\hline $\begin{array}{l}0.90 \leq \text { Comprehensive efficiency } \\
<0.95\end{array}$ & 8 & 7 & 6 & $21 \%$ & $18 \%$ & $16 \%$ \\
\hline Comprehensive efficiency $<0.90$ & 2 & 4 & 3 & $5 \%$ & $11 \%$ & $8 \%$ \\
\hline
\end{tabular}

(2) Descriptive statistics on factors affecting the operating efficiency of listed military enterprises Table 4 gives descriptive statistics on the variables of potential factors, with the average share ratio of the top ten shareholders of the listed military enterprises at around 60\% from 2014 to 2016. Among them, CSSC Offshore \& Marine Engineering Group Limited has the highest share concentration, with the top 10 shareholders' owning more than 80\% shares. Meanwhile, shareholders of Haige Communications Group Incorporated Company own the lowest proportion of shares, which was about $30 \%$. The overall variance of the samples is about 0.1 , which indicates that the share concentration gap between the samples is relatively large. In general, the shares of listed military enterprises are relatively concentrated. 30 sample enterprises are state-holding, and only 8 are non-state-holding, indicating that the current listed military enterprises are mostly state-holding. The proportion of R\&D investment to operating revenue shows a trend of increasing year by year, which shows that listed military enterprises attach great importance to R\&D investment for enhancing their technical advantages. The gap of investment in R\&D between the sample companies was also quite large. In 2015, R\&D investment of XI'an Tianhe Defense Technology Co., Ltd accounted for $80 \%$ of the operating revenue. During the same period, R\&D investment of AVIC accounted for only $0.61 \%$ of operating revenue. The gap was as high as a hundred times. Proportion of government grants to operating income showed a trend of first growth and then decline. In 2016, the government grants of DALI Technology Co., Ltd accounted for $72 \%$ of its operating revenue, while government grants of the sample companies accounted for nearly $80 \%$ of their net profit in the same period. It shows that the policy support of government to the military industry is large, and much of operating performance of listed military companies came from the high government grants. 
INTERNATIONAL JOURNAL OF ACADEMIC RESEARCH IN BUSINESS AND SOCIAL SCIENCES Vol. 9, No. 4, April, 2019, E-ISSN: 2222-6990 @ 2019 HRMARS

Table 4: Descriptive Statistics of Variables

\begin{tabular}{|c|l|l|l|l|l|l|l|}
\hline Year & Statistic & $\begin{array}{l}\text { Operating } \\
\text { Efficiency }\end{array}$ & $\begin{array}{l}\text { Sum of the } \\
\text { Shares of the } \\
\text { Top 10 } \\
\text { Shareholders }\end{array}$ & $\begin{array}{l}\text { Proportio } \\
\text { n of State- } \\
\text { Owned } \\
\text { Shares }\end{array}$ & $\begin{array}{l}\text { Proportion } \\
\text { of R\&D } \\
\text { Investment } \\
\text { to Operating } \\
\text { Revenue }\end{array}$ & $\begin{array}{l}\text { Proportion of } \\
\text { Government } \\
\text { Grants to } \\
\text { Operating } \\
\text { Revenue }\end{array}$ & $\begin{array}{l}\text { Natural } \\
\text { logarithm } \\
\text { of Total } \\
\text { Assets }\end{array}$ \\
\hline \multirow{5}{*}{2014} & Max & 1.0000 & $82.08 \%$ & $59.07 \%$ & $41.42 \%$ & $18.34 \%$ & 24.67 \\
\cline { 2 - 7 } & Min & 0.8470 & $32.22 \%$ & $0.00 \%$ & $0.00 \%$ & $0.22 \%$ & 20.53 \\
\cline { 2 - 7 } & Average & 0.9658 & $60.52 \%$ & $5.59 \%$ & $6.81 \%$ & $3.66 \%$ & 22.21 \\
\cline { 2 - 7 } & Median & 0.9775 & $60.02 \%$ & $0.00 \%$ & $4.76 \%$ & $1.73 \%$ & 21.96 \\
\cline { 2 - 7 } & $\begin{array}{l}\text { Standard } \\
\text { Deviation }\end{array}$ & 0.0382 & 0.1236 & $13.40 \%$ & 0.0794 & 0.0404 & 1.10 \\
\hline \multirow{5}{*}{2015} & Max & 1.0000 & $87.74 \%$ & $59.11 \%$ & $62.70 \%$ & $34.16 \%$ & 24.66 \\
\cline { 2 - 7 } & Min & 0.8010 & $32.92 \%$ & $0.00 \%$ & $0.57 \%$ & $0.16 \%$ & 20.87 \\
\cline { 2 - 7 } & Average & 0.9643 & $60.36 \%$ & $5.58 \%$ & $8.30 \%$ & $3.94 \%$ & 22.40 \\
\cline { 2 - 7 } & Median & 0.9830 & $61.29 \%$ & $0.00 \%$ & $4.63 \%$ & $2.05 \%$ & 22.18 \\
\hline & $\begin{array}{l}\text { Standard } \\
\text { Deviation }\end{array}$ & 0.0450 & 0.1173 & $12.37 \%$ & 0.1073 & 0.0628 & 1.07 \\
\hline \multirow{5}{*}{2016} & Max & 1.0000 & $84.86 \%$ & $33.44 \%$ & $28.67 \%$ & $37.10 \%$ & 24.68 \\
\cline { 2 - 7 } & Min & 0.8250 & $37.12 \%$ & $0.00 \%$ & $1.32 \%$ & $0.18 \%$ & 20.86 \\
\cline { 2 - 7 } & Average & 0.9687 & $60.09 \%$ & $4.59 \%$ & $7.37 \%$ & $3.52 \%$ & 22.53 \\
\cline { 2 - 7 } & Median & 0.9905 & $60.12 \%$ & $0.00 \%$ & $4.89 \%$ & $1.73 \%$ & 22.33 \\
\cline { 2 - 7 } & $\begin{array}{l}\text { Standard } \\
\text { Deviation }\end{array}$ & 0.0422 & 0.1059 & $8.99 \%$ & 0.0713 & 0.0609 & 1.06 \\
\hline
\end{tabular}

Test of Factors Affecting Operating Efficiency

This paper uses the econometrics software package called Eviews to examine the model selection and influencing factors. It first tests the rationality of model selection, which means the validity and rationality of the model are determined by $F$ test and Hausman test. The value of $F$ test is 5.3036 ( $P$ value is 0 ), so we reject the assumption that different individuals have the same intercept term, thus the model of individual fixed effect is better than the model of mixed effect. Chi-square value of Hausman test is 7.6496 ( $P$ value is 0.0177 ), so the individual fixed effect model is better than the random effect model. Therefore, the individual fixed effect model adopted in this paper is effective and reasonable.

Table 5: Verification results of influencing factors of operating efficiency (Individual Fixed Effect Model)

\begin{tabular}{|l|l|l|l|l|}
\hline $\begin{array}{l}\text { Variable } \\
\text { Name }\end{array}$ & Regression Coefficient & Standard Deviation & T value & P value \\
\hline Top & -0.0126 & 0.0747 & -0.1682 & 0.8669 \\
\hline State & 0.0451 & 0.0283 & 1.5937 & 0.1154 \\
\hline R\&D & 0.1659 & 0.0591 & 2.8099 & $0.0059^{* * *}$ \\
\hline Scale & 0.0177 & 0.0089 & 1.9961 & $0.0498^{* *}$ \\
\hline Subsidy & -0.1658 & 0.0900 & -1.8411 & $0.0683^{*}$ \\
\hline
\end{tabular}


INTERNATIONAL JOURNAL OF ACADEMIC RESEARCH IN BUSINESS AND SOCIAL SCIENCES Vol. 9, No. 4, April, 2019, E-ISSN: 2222-6990 @ 2019 HRMARS

(Note $: \mathrm{R}^{2}=0.8896, \mathrm{~F}$-statistic $=13.6283, \operatorname{Prob}(\mathrm{F}$-statistic) $=0.0000, *, * *, * * *$ separately indicate that variables are significantly correlated at level $10 \%$, level $5 \%$ and level $1 \%$.)

The empirical test results of the influencing factors are as follows, through which we can find:

(1) The share concentration coefficient is negative $(-0.0126)$ and it does not pass the significance test, so Assumption 1 does not hold true. At the present stage, the share concentration of listed military companies has little effect on the operating efficiency. It shows that the military industry is different from the general industries, and its particularity determines that military assets must be in the hands of the state. At present, the majority of the controlling shareholders of listed military companies are the state or government agencies. The average share of state-owned shareholders of the samples in 2016 was $40 \%$, but other large shareholder's share ratio cannot compete with it obviously.

(2) The proportion coefficient of state-owned shares is positive (0.0451) and the significance level is under $10 \%$, which is not consistent with Assumption 2 . Although the proportion of state-owned shares has little effect on the operating efficiency, the correlation coefficient's being positive indicates that operating efficiency can be improved by high state-owned share. It means that state shareholders can also use their own institutional and administrative resources to provide listed military companies with policy support or special market opportunities to let them have resource advantage that helps them obtain special competitive advantage, thus positively affecting operating performance. Therefore, for listed military companies, high proportion of state-owned shares will be conducive to its development.

(3) R\&D investment has significant positive effects on the operating efficiency of listed military companies. The military industry needs support from a lot of advanced technologies and knowledge and other resources. Compared with civil industry, military industry needs more technology accumulation. Listed military companies can increase their own R\&D investment to enhance the overall technical level, and make a breakthrough via continuous R\&D investment and increasing industrial strength. China's civil-military integration strategy also promotes social capital entering into the production and research system of military products, thus improving the efficiency of production and R\&D.

(4) The expansion of company scale has a significant positive impact on the operating efficiency of listed military companies. Military industry concentrates massive frontier technologies, capital and other resources. Assets of sample companies are all more than 1 billion yuan. Large military and civilian heavy industries tend to have the characteristics of natural monopoly, and centralized production can effectively reduce the average production cost. With the promotion of civilmilitary integration, listed military companies expand their asset scale and business scale, reduce transaction cost and use scale economy to improve production efficiency through asset reorganization and merger, etc. Therefore, listed military companies should expand company scale through resource integration to make better use of the scale effect.

(5) Government grants have a weak negative effect on the operating efficiency of listed military companies. In this paper, net profit is subtracted from non-recurring profit when selecting the index of input-output efficiency of production and operation. This indicator, however, excludes government grants that account for current gains and losses from disclosed net profit. Judging from the impact on overall efficiency, government grants may reduce the operating efficiency of 
listed military companies. The government's policy support to the military industry has improved the operating performance of listed military companies in the short term, but it is not conducive to the companies' rapid adaptation and quick response to the market environment. Long-term grants are not conducive to the improvement of company governance.

\section{Countermeasures and Recommendations}

In the context of the integration of military and civilian, the improvement of the operational efficiency of military listed companies is imminent, and should be:

(1) Promote technological innovation and civilian use of military technology Strengthening technological innovation by military listed companies is not only the need of national security construction, but also the need to adapt to market competition to achieve the company's maximum economic benefits and enhance its core competitiveness. R\&D investment is an important factor for military listed companies to promote technological innovation. Technological innovation has prompted military listed companies to develop new products, adopt new production technologies, gain market competitive advantages and higher profits, and then carry out a virtuous cycle of R\&D investment to maintain the sustainable development of military listed companies. At the same time, military-listed companies must implement the requirements of the "military-civilian integration strategy". On the one hand, they must give play to the innovative advantages of the military industry and promote the transformation of military technology into the civilian sector, resulting in spillover effects.

(2) Promote resource integration to enhance economies of scale Military listed companies should give full play to the platform role of the capital market, promote the injection of high-quality assets within the group and increase the rate of securitization of military assets. In addition, through asset restructuring, mergers and acquisitions and industrial integration, it is also beneficial for military listed companies to expand the company's scale and promote efficiencyoriented resource optimization at the micro level. Military listed companies integrate industrial resources through capital market to improve industrial concentration is the best way to use scale effect to become bigger and stronger.

(3) Improve military listed companies' management Chinese military industrial enterprises are established under the planned economic system. In the process of transition to a market economy the company's lack of market competition awareness, lack of crisis awareness and industry monopoly awareness. Military listed companies should actively establish a modern enterprise management system that meets the requirements of the market economy, promote efficient internal operations and rational allocation of resources, reduce unnecessary waste of manpower and capital, and increase operational efficiency to the frontier of production.

In short, we must constantly reform and innovate the management system of the company, and strive to achieve efficient value creation with solid management, strong market competitiveness and excellent performance. 
INTERNATIONAL JOURNAL OF ACADEMIC RESEARCH IN BUSINESS AND SOCIAL SCIENCES

Vol. 9, No. 4, April, 2019, E-ISSN: 2222-6990 C 2019 HRMARS

\section{Acknowledgements}

The paper was supported by the Planning Fund of Education Ministry for Humanities and Social Sciences (NO: 18YJAZH010) and the Fundamental Research Funds for the Central Universities (NO: NR2018010, NJ2019022).

\section{References}

Singh, F. \& Mogla, M. (2010). Profitability Analysis of Acquiring Companies. IUP Journal of Applied Finance, 16(5), 72-83.

Martins, M. M. \& Lopes, I.T. (2016). Intellectual Capital and Profitability: A Firm Value Approach in the European Companies. Business: Theory \& Practice, 17(3), 234-242.

Zhang, J. H., \& Qiao, J. J. (2016). The Research of Civil-military Integration In-depth Development Pattern. Journal of Beijing Institute of Technology (Social Sciences Edition), 18(05), 111-116.

Pan, Y., Zhou, Z. \& Zhang, Y. Z. (2017). The Development Trend and Suggestions of Military Industry in China from the Perspective of Civil-Military Integration. Economic Review Journal, 3, 74-82.

Guo, Y. H. (2014). Analysis on Technology Innovation of Civil- military Integration from Institutional View. Science and Technology Management Research, 34(03), 14-17.

Li, Y., Wu, S. H. \& Guo, J. H. (2015). The Choice of Paths for Third-tie Military Enterprise Transformation \& Upgrading and its Influencing. Science \& Technology Progress and Policy, 32(18), 98-103.

Wang, B. J. \& Li, A. W. (2016). An Analysis on Calculation and Influencing Factors of the Technical Efficiency in Civil-military Integration Enterprises- - Evidence from the Listed Companies of "Ten Military Groups" of China. Science and Technology Management Research, 36(23), 6773.

Zhou, J. (2012). Empirical Analysis on the Relationships between Ownership Structure and Performance of Military Listed Companies. East China Economic Management, 26(01), 110112.

Charnes, A., Cooper, W. W. \& Rhodes, E. (1978). Measuring the Efficiency of Decision-Making Units. European Journal of Operational Research, 2(6), 429-444. 